\title{
Altered Aldose Reductase Gene Regulation in Cultured Human Retinal Pigment Epithelial Cells
}

\author{
Douglas N. Henry, ** Monte Del Monte, ${ }^{5}$ Douglas A. Greene, ${ }^{\star}$ and Paul D. Killen" \\ The Departments of *Pediatrics and Communicable Diseases, ${ }^{\S}$ Ophthalmology, ${ }^{\ddagger}$ Internal Medicine and $"$ Pathology, \\ and the Michigan Diabetes Research and Training Center, University of Michigan, Ann Arbor, Michigan 48109
}

\begin{abstract}
Aldose reductase (AR2"), a putative "hypertonicity stress protein" whose gene is induced by hyperosmolarity, protects renal medullary cells against the interstitial hyperosmolarity of antidiuresis by catalyzing the synthesis of millimolar concentrations of intracellular sorbitol from glucose. Although AR2 gene induction has been noted in a variety of renal and nonrenal cells subjected to hypertonic stress in vitro, the functional significance of AR2 gene expression in cells not normally exposed to a hyperosmolar milieu is not fully understood. The physiological impact of basal AR2 expression in such cells may be limited to hyperglycemic states in which AR2 promotes pathological polyol accumulation, a mechanism invoked in the pathogenesis of diabetic complications. Since AR2 overexpression in the retinal pigment epithelium has been associated with diabetic retinopathy, the regulation of AR2 gene expression and associated changes in sorbitol and myo-inositol were studied in human retinal pigment epithelial cells in culture. The relative abundance of aldehyde reductase (AR1) and AR2 mRNA was quantitated by filter hybridization of RNA from several human retinal pigment epithelial cell lines exposed to hyperglycemic and hyperosmolar conditions in vitro. AR2 but not AR1 mRNA was significantly increased some 11- to 18-fold by hyperosmolarity in several retinal pigment epithelial cell lines. A single cell line with a 15-fold higher basal level of AR2 mRNA than other cell lines tested demonstrated no significant increase in AR2 mRNA in response to hypertonic stress. This cell line demonstrated accelerated and exaggerated production of sorbitol and depletion of myo-inositol upon exposure to $20 \mathrm{mM}$ glucose. Therefore, abnormal AR2 expression may enhance the sensitivity of cells to the biochemical consequences of hyperglycemia potentiating the development of diabetic complications. ( $J$. Clin. Invest. 1993. 92:617-623.) Key words: diabetic retinopathy $\bullet$ aldehyde reductase $\bullet$ myo-inositol $\bullet$ sorbitol $\bullet$ osmolyte
\end{abstract}

Parts of this work have appeared in abstract form at the 50th Annual Meeting, American Diabetes Association, June 16-19, 1990, Atlanta, GA; 14th International Diabetes Federation Congress, June 23-28, 1991, Washington, DC; and the 52nd Annual Meeting, American Diabetes Association, June 20-23, 1992, San Antonio, TX.

Address reprint requests to Douglas A. Greene, M.D., Division of Endocrinology and Metabolism, Department of Internal Medicine, University of Michigan Medical Center, 3920 Taubman Center, Box 0354, 1150 East Medical Center Drive, Ann Arbor, MI 48109-0354.

Received for publication 31 December 1992 and in revised form 12 March 1993.

J. Clin. Invest.

(c) The American Society for Clinical Investigation, Inc.

0021-9738/93/08/0617/07 \$2.00

Volume 92, August 1993, 617-623

\section{Introduction}

Hyperglycemia has been strongly implicated in the development of the chronic complications of diabetes, but the specific pathogenetic pathways and their possible modulation by genetic and environmental factors remain the subject of speculation and controversy (1). Metabolism of excess tissue glucose to sorbitol by the enzymes aldehyde and aldose reductase (AR ${ }^{1}$ [EC 1.1.1.2] and AR2 [EC 1.1.1.21], respectively) has recently received widespread consideration as a potentially important tissue-specific mechanism of glucose toxicity $(2,3)$. Some of the potential adverse effects of increased glucose flux through the sorbitol pathway have been ascribed to secondary alterations in intracellular myo-inositol (MI) metabolism (4) perhaps due to depletion of specific intracellular MI pools (5, 6 ). The mechanisms leading to depletion of intracellular MI is poorly understood, but may be due to the action of sorbitol and MI as alternative non-ionic intracellular osmolytes (7). Accumulation of intracellular sorbitol may be accompanied by reciprocal decreases in other intracellular osmolytes, such as MI, betaine, or glycerophosphorylcholine in order to maintain osmotic equilibrium. Other mechanisms by which increased flux through the sorbitol pathway might cause tissue damage include perturbation in the $\mathrm{NADP}^{+} / \mathrm{NADPH}$ and $\mathrm{NAD}^{+} /$ $\mathrm{NADH}$ redox couples linked to the AR and sorbitol dehydrogenase oxidoreductase enzymes, respectively $(8,9)$, and/or direct osmotic effects of accumulated intracellular sorbitol (10).

Osmotic stress has recently emerged as a major regulator of the genes for AR2 and the $\mathrm{Na}^{+}-\mathrm{MI}$ cotransporter in the renal medulla, where sorbitol and MI function physiologically as intracellular osmolytes that compensate for the high interstitial osmolarity required for antidiuresis $(7,11)$. Under these circumstances, elevated extracellular osmolarity is thought to increase AR2 and MI-transporter gene expression, protein synthesis, and activity $(11,12)$. Increased AR2 gene expression, immunoreactivity and enzymatic activity in a variety of tissues and cells have also been associated with diabetes and its chronic complications in man and animals (13-15). AR2 immunoreactivity is increased in the retinal pigment epithelial (RPE) cell layer in eyes obtained at autopsy from diabetic subjects with and without proliferative diabetic retinopathy, with a greater increase in the former (13). The RPE cell layer exhibits sorbitol accumulation, $\mathrm{MI}$ depletion, and impaired $\mathrm{Na}^{+} /$ $\mathrm{K}^{+}$-ATPase activity in diabetic rabbits $(16,17)$. Moreover, electroretinographic impairment in diabetic pigmented rats is ascribed to dysfunction of the RPE cell layer and is corrected by either aldose reductase inhibitors (ARI) or by MI supple-

1. Abbreviations used in this paper: ARI, aldose reductase inhibitors; AR1, aldehyde reductase; AR2, aldose reductase; MI, myo-inositol; RPE, retinal pigment epithelial. 
mentation (18). Therefore, cultured RPE cells from a variety of mammalian species including humans have been examined as an in vitro model of biochemical and functional defects that may contribute to the pathogenesis of some diabetic complications in vivo $(19,20)$. Human RPE cells in culture demonstrate glucose-induced, ARI-sensitive MI depletion, which is associated with a reversible reduction in the rate of uptake of ${ }^{125}$ I-labeled human retinal rod outer segments, an important function of the RPE cell (20). The supposition that altered AR2 (and/or AR1) gene expression might predispose diabetic patients to chronic tissue-specific complications such as retinopathy prompted this study of AR1 and AR2 gene modulation by osmolarity in RPE cells. The results demonstrate that aberrant AR2 gene expression is associated with accelerated sorbitol accumulation and MI depletion in response to pathophysiological levels of glucose, suggesting that dysregulation of the AR2 gene may be a predisposing factor to glucose-induced metabolic abnormalities in RPE cells and, by extrapolation, in other tissues prone to diabetic complications.

\section{Methods}

Reagents and supplies. Unless otherwise indicated, culture media, antibiotics, and trypsin were obtained from GIBCO BRL (Life Technologies Inc.), Gaithersburg, MD; fetal bovine and calf serum from Hyclone Labs, Logan, UT; culture dishes, wells, and flasks from Falcon (Becton-Dickinson and Co., Lincoln Park, NJ); chemicals and reagents (highest available purity) from Sigma Chemical Co., St. Louis, MO; and radioisotopes were from Amersham Corp., Arlington Heights, IL.

Cell culture techniques and experimental design. Primary cultures of RPE cells were established and maintained by the method of Del Monte and Maumenee (21) as recently modified (20). In brief, RPE cells were recovered with fire-polished Pasteur pipettes under direct observation with a dissecting microscope from surgically removed, sagittally bisected eyes, obtained from the Michigan Eye Bank within 24 $\mathrm{hr}$ post-mortem, and cultured in Ham's $\mathrm{F} 12$ nutrient medium containing $16 \%$ FBS, $2 \mathrm{mM}$ glutamine, $100 \mathrm{U} / \mathrm{ml}$ penicillin, $100 \mu \mathrm{g} / \mathrm{ml}$ streptomycin, and $26 \mathrm{mM}$ sodium bicarbonate in a $37^{\circ} \mathrm{C}$, humidified $5 \%$ $\mathrm{CO}_{2}$ atmosphere. Colony-forming primary cultures were rinsed with Hanks' balanced salt solution and passaged with $0.5 \mathrm{mg} / \mathrm{ml}$ trypsin and $0.53 \mathrm{mM}$ EDTA in normal saline at $37^{\circ} \mathrm{C}$ for $10 \mathrm{~min}$, centrifuged for $5 \mathrm{~min}$ at $50 \mathrm{~g}$, resuspended in new culture medium and replated (21). The established RPE cell lines were passaged at a density of 40100,000 cells $/ \mathrm{cm}^{2}$ in $25 \mathrm{~cm}^{2}$ or $75 \mathrm{~cm}^{2}$ flasks in MEM with $2 \mathrm{mM}$ L-glutamine $([\mathrm{MI}]=11.1 \mu \mathrm{M})$ containing $20 \%$ calf serum $([\mathrm{MI}]$ $=90-120 \mu \mathrm{M})$ and $5 \mathrm{mM}$ glucose (20). All experiments were performed between passages 19 and 24 of 4 RPE cell lines described in Table I. Passaged cells were plated to yield near-confluent cultures at the end of 1- and 7-d experiments $(20)$. Six-well plates $\left(9.62 \mathrm{~cm}^{2}\right)$ or $175 \mathrm{~cm}^{2}$ dishes were used for metabolic studies or RNA isolation, respectively. The freshly plated cells were allowed to attach in standard growth medium for $24 \mathrm{~h}$ and then incubated for various times in MEM containing $5 \%$ calf serum and various supplements (see below). RPE cells (lines 125, 45 and 91) were incubated in medium containing 300 mM glucose for $0,2,4,8,16$ or $24 \mathrm{~h}$ to determine when AR2 mRNA induction was maximal. Subsequent experiments (RPE cell lines 125, 0308,45 , and 91 ) compared the effect of $300 \mathrm{mM}$ glucose, 3-O-methylglucose or mannitol on AR2 mRNA levels attained at each time point. The effect of various concentrations of glucose on AR1 and AR2 mRNA were examined after $24 \mathrm{~h}$. These studies were performed in triplicate using RPE 125 or 45 cells. Further experiments compared the response of $4 \mathrm{RPE}$ cell lines to $20 \mathrm{mM}$ or $300 \mathrm{mM}$ glucose at $24 \mathrm{~h}$ or $7 \mathrm{~d}$. $20 \mathrm{mM}$ glucose simulated physiological hyperglycemia $(20)$ where flux through the polyol pathway would be stimulated primarily by mass action (8). $300 \mathrm{mM}$ glucose was considered a combined osmotic stimulus in the presence of maximal substrate concentrations for the AR reactions. Cultures were routinely examined by phase contrast microscopy and survival estimated by trypan blue exclusion. Neither cell morphology nor survival was detectable altered by the experimental conditions employed in these studies.

Preparation of AR1 and AR2 cDNA from RPE mRNA by PCR amplification. Total RNA was purified from cultured human RPE cells by a modification of the method of Stallcup and Washington (22). Oligo-dT primed cDNA was prepared from $20 \mu \mathrm{g}$ of total RPE cell RNA and reverse transcribed with Superscript (Bethesda Research Laboratories, Gaithersburg, MD) according to the vendor's protocol. AR1 and AR2 cDNAs were selectively PCR amplified using Amplitaq (Perkin-Elmer Corp., Norwalk, CT), the vendor's buffer and synthetic oligonucleotide primers for human hepatic AR1 (5'TATAAGCTTGCTACGACTCCACCCACTA3' and 5'ATATCTAGATGHCTTCATCTCTTCTGGGCT3') and placental AR2 (5'TATAAGCTTAGAAGCTCAGGGAGCAGGT3' and 5'ATATCTAGAGGTCACCACGATGCCTTTG3') cDNA (23), anchored with either HindIII or $\mathrm{Xbal}$ sites. Oligonucleotides were synthesized by the DNA Synthesis Core Facility, a part of the University of Michigan's Biomedical Research Core Facilities, on automated DNA synthesizers (Applied Biosystems, Inc., Foster City, CA) employing $\beta$-cyanoethyl phophoramidite chemistry on controlled pore glass support. After 30 cycles $\left(95^{\circ} \mathrm{C}\right.$, $1.5 \mathrm{~min}$ denaturation; $54^{\circ} \mathrm{C}, 1.5 \mathrm{~min}$ annealing; and $72^{\circ} \mathrm{C}, 1.5 \mathrm{~min}$ extension) a single major amplification product was identified for each primer pair. The subcloned amplification products obtained with AR1 or AR2 primers each exhibited $100 \%$ sequence identity with human hepatic AR1 and placental AR2 cDNAs (23), respectively, but had only $35 \%$ nucleotide identity with each other. The purified cDNA inserts for RPE AR1 and AR2 were labeled with random primers and $\left[{ }^{32} \mathrm{P}\right] \mathrm{dCTP}\left(3000 \mathrm{Ci} / \mathrm{mM}\right.$; Amersham) to a specific activity of $10^{9}$ $\mathrm{dpm} / \mu \mathrm{g}(24)$.

Filter hybridization of $R N A$ from $R P E$ cells. $10 \mu \mathrm{g}$ of denatured total RNA was resolved on $2.2 \mathrm{M}$ formaldehyde $1 \%$ agarose gels, transferred by capillary blotting to Zetabind filters (Cuno, Inc., Meriden, CT) stained with methylene blue and photographed. Because of the large differences in the abundance of AR2 mRNA in many of the samples, quantitation was performed with serial dilutions (64- to 128fold) of RNA applied with a vacuum manifold to Zetabind filters. The filters were fixed in vacuo at $80^{\circ} \mathrm{C}$ for $2 \mathrm{~h}$, and prehybridized at $65^{\circ} \mathrm{C}$ in $0.5 \mathrm{M} \mathrm{NaH}_{2} \mathrm{PO}_{4} \mathrm{pH} \mathrm{7.0,1} \mathrm{mM}$ EDTA, 7\% SDS, and 1\% BSA for 4-6 $\mathrm{h}$ before adding the denatured AR2 cDNA probe $\left(10^{6} \mathrm{dpm} / \mathrm{ml}\right)(25)$. After $18 \mathrm{~h}$, filters were washed twice with $40 \mathrm{mM} \mathrm{NaH}_{2} \mathrm{PO}_{4} \mathrm{pH} \mathrm{7.0,1}$ mM EDTA, $7 \%$ SDS at $65^{\circ} \mathrm{C}$, and 4 times with $40 \mathrm{mM} \mathrm{NaH}_{2} \mathrm{PO}_{4} \mathrm{pH}$

Table I. Human Retinal Pigment Epithelial Cell Lines Used in These Studies

\begin{tabular}{|c|c|c|c|c|c|c|}
\hline Cell line & Male/Female & Age & $\begin{array}{c}\text { Cause of } \\
\text { death }\end{array}$ & $\begin{array}{l}\text { Hours to } \\
\text { enucleation }\end{array}$ & $\begin{array}{l}\text { Hours to } \\
\text { culture }\end{array}$ & $\begin{array}{l}\text { Passage } \\
\text { number }\end{array}$ \\
\hline 125 & Male & 12 & Gunshot & 8 & 22 & 24 \\
\hline 0308 & Male & 15 & MVA & 5 & 14 & 23 \\
\hline 45 & Female & 50 & CVA & 5.75 & 21 & 21 \\
\hline 91 & Female & 54 & CVA & 2.5 & 21 & 19 \\
\hline
\end{tabular}


$7.0,1 \mathrm{mM}$ EDTA, $1 \%$ SDS at $65^{\circ} \mathrm{C}$, and exposed to preflashed photographic film (X-Omat; Eastman-Kodak, Rochester, NY) at $-80^{\circ} \mathrm{C}$ in cassettes with intensifying screens. Exposures of the dot blot filters within the linear range of the film were quantitated by densitometry. Filters were subsequently stripped, reexposed, and, when free of residual probe, sequentially rehybridized with AR1, chicken $\beta$-actin (26), or human vimentin cDNA probes (27). Densitometry results from three replicate samples obtained in three independent experiments were normalized for the abundance of $\beta$-actin mRNA, and statistical analysis was performed using analysis of variance with repeat measurements design (28).

Measurement of sorbitol and MI in cultured RPE cells. Confluent monolayers of RPE cells in six-well plates were rinsed with $3 \mathrm{ml}$ of serum-free MEM containing $3.5 \mathrm{mg} / \mathrm{ml} \mathrm{BSA}$, lysed in $1 \mathrm{ml}$ distilled $\mathrm{H}_{2} \mathrm{O}$ for $15 \mathrm{~min}$ at $37^{\circ} \mathrm{C}$, and scraped with a rubber policeman into 3-ml plastic tubes, sonicated, and deproteinized with balanced aliquots of $5 \% \mathrm{ZnSO}_{4}$ and $\mathrm{Ba}(\mathrm{OH})_{2}$ followed by centrifugation. Aliquots of the supernatant were combined with the internal standard $\alpha$-D-mannoside, lyophilized, derivitized with a 10:2:1 solution of dried pyridine-hexamethyldisilizane-trimethylchlorsilane (Pierce, Rockford, IL), evaporated to dryness under $\mathrm{N}_{2}$, resolubilized in hexane and injected into a gas-liquid-chromatograph (3400; Varian Instruments, Palo Alto, CA) fitted with a flame ionization detector and a 30-m DB-Megabore column (J\&W Sci., Folsom, CA) with helium as a carrier, and programmed from 160 to $210^{\circ} \mathrm{C}$ as previously described (20). Peak areas were digitally quantitated with a Varian $\mathbf{4 0 2}$ data system, corrected for the internal standard, and transformed to mass measurements on the basis of daily standard curves for $\alpha$-D-mannoside, sorbitol, and MI (20). Statistical analysis was performed using analysis of variance with repeat measurements design (26).

\section{Results}

Induction of AR2 $\mathrm{mRNA}$ but not AR1 $\mathrm{mRNA}$ in RPE cells in vitro. The increase in AR2 mRNA induced by glucose in RPE cell lines 125, 0308, and 45 was time and concentration dependent (Figs. 1 and 2). Increased AR2 mRNA was first evident after $8 \mathrm{~h}$ exposure to $300 \mathrm{mM}$ glucose, achieving near maximal steady-state levels after $16 \mathrm{~h}$ (Fig. 1). 7 d exposure to $300 \mathrm{mM}$ glucose resulted in only a slight (30\%) decline in AR2 mRNA from the maximal level noted at $24 \mathrm{~h}$ (data not shown). Increased AR2 mRNA was evident after $24 \mathrm{~h}$ exposure to medium containing $150 \mathrm{mM}$ glucose ( $440 \mathrm{mosmol} / \mathrm{kg}$ ), however no significant increase in AR2 mRNA was noted at lesser glu-

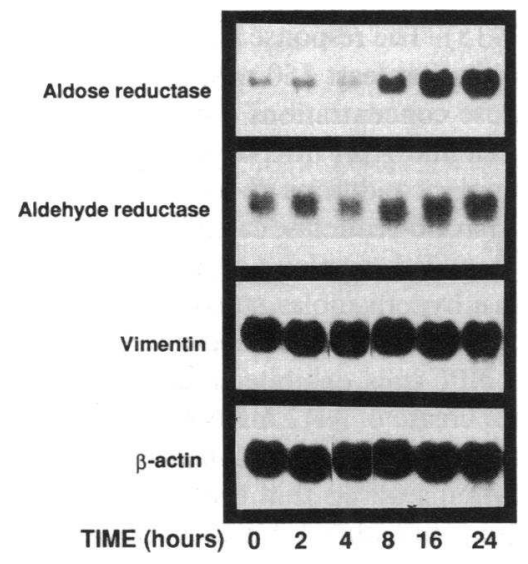

Figure 1. Time course of AR2 mRNA induction by $300 \mathrm{mM}$ glucose. RNA was isolated from RPE cell line 125 after $0,2,4,8,16$, and $24 \mathrm{~h}$ exposure to 300 $\mathrm{mM}$ glucose. A Northern blot was sequentially hybridized with AR1, AR2, $\beta$-actin, and vimentin CDNA probes. Increased AR2 mRNA was first noted after $8 \mathrm{~h}$ exposure and was near maximal by $16 \mathrm{~h}$. No significant change in $\mathrm{AR} 1$, vimentin, or $\beta$ actin mRNA was evident.

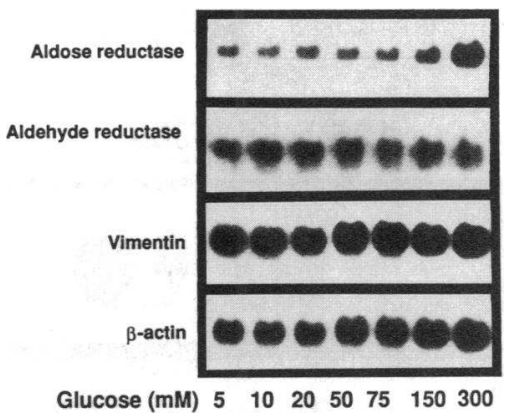

Figure 2. Dose response of AR2 mRNA to glucose. RNA was isolated from RPE cell line 45 after $24 \mathrm{~h}$ exposure to various glucose concentrations. A Northern blot was sequentially hybridized with AR1, $\mathrm{AR} 2, \beta$-actin, and vimentin cDNA probes. Increased AR2 mRNA was first evident following exposure to $150 \mathrm{mM}$ glucose and was near maximal at $300 \mathrm{mM}$ glucose. No significant change in AR1, $\beta$-actin, or vimentin mRNA was apparent at any glucose concentration.

cose concentrations (Fig. 2) even after $7 \mathrm{~d}$ (data not shown). No significant change in AR1, vimentin or $\beta$-actin mRNA was noted at any glucose concentration at any time (Figs. 1 and 2). The effect of $300 \mathrm{mM}$ glucose was reproduced by an equimolar concentration of the nonmetabolizable glucose analogue, 3-Omethylglucose, or by mannitol, an osmotically active nonionic compound that does not undergo facilitated transport (Fig. 3).

Constitutive AR2 gene expression in RPE 91 cells. An effect of glucose on the expression of AR2 mRNA was significant only in RPE 125,0308 , and 45 cells $(P<0.02)$. Exposure to medium supplemented with $300 \mathrm{mM}$ glucose $(590 \mathrm{mosmol} /$ $\mathrm{kg}$ ) resulted in a marked increase (17.7-, 17.7-, and 11.3-fold, respectively) in AR2 mRNA after $24 \mathrm{~h}$ (Figs. 4 and 5). In agreement with previous data, $20 \mathrm{mM}$ glucose has no effect on AR2 mRNA levels in any cell line $(P>0.05)$. The mRNA encoding AR1, another oxido-reductase capable of metabolizing glucose to sorbitol, was not significantly changed by this treatment, and no significant change in vimentin or $\beta$-actin mRNA was noted (Fig. 4). In contrast, the basal level of AR2 mRNA in RPE 91 cells (isotonic medium, $5 \mathrm{mM}$ glucose) was 14- to 17-fold higher than the basal AR2 mRNA level in RPE 125,0308 , or 45 cells $(P<0.001)$, and there was no significant increase in AR2 mRNA after exposure to $300 \mathrm{mM}$ glucose for $24 \mathrm{~h}$ or $7 \mathrm{~d}$ (Figs. 4-6).

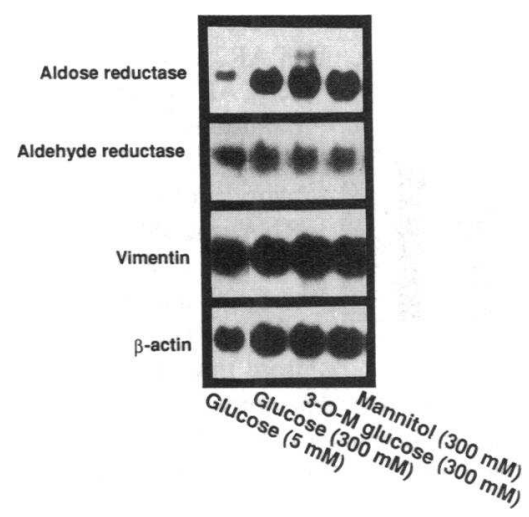

Figure 3. Induction of AR2 mRNA by glucose, 3-O-methylglucose, and mannitol. RNA was isolated from RPE cell line 45 after $24 \mathrm{~h}$ exposure to $5 \mathrm{mM}$ glucose, $300 \mathrm{mM}$ glucose, 300 $\mathrm{mM}$ 3-O-methylglucose, and $300 \mathrm{mM}$ mannitol. A Northern blot was sequentially hybridized with AR1, AR2, $\beta$-actin, and vimentin $\mathrm{CDNA}$ probes. Glucose, 3-Omethylglucose, a nonmetabolizable glucose analogue, and mannitol, an osmotically active, non-ionic compound that does not undergo facilitated transport, were similarly effective in increasing AR2 mRNA levels. No significant change in AR1, vimentin, or $\beta$-actin mRNA was evident. 


\section{RPE CELL LINE}

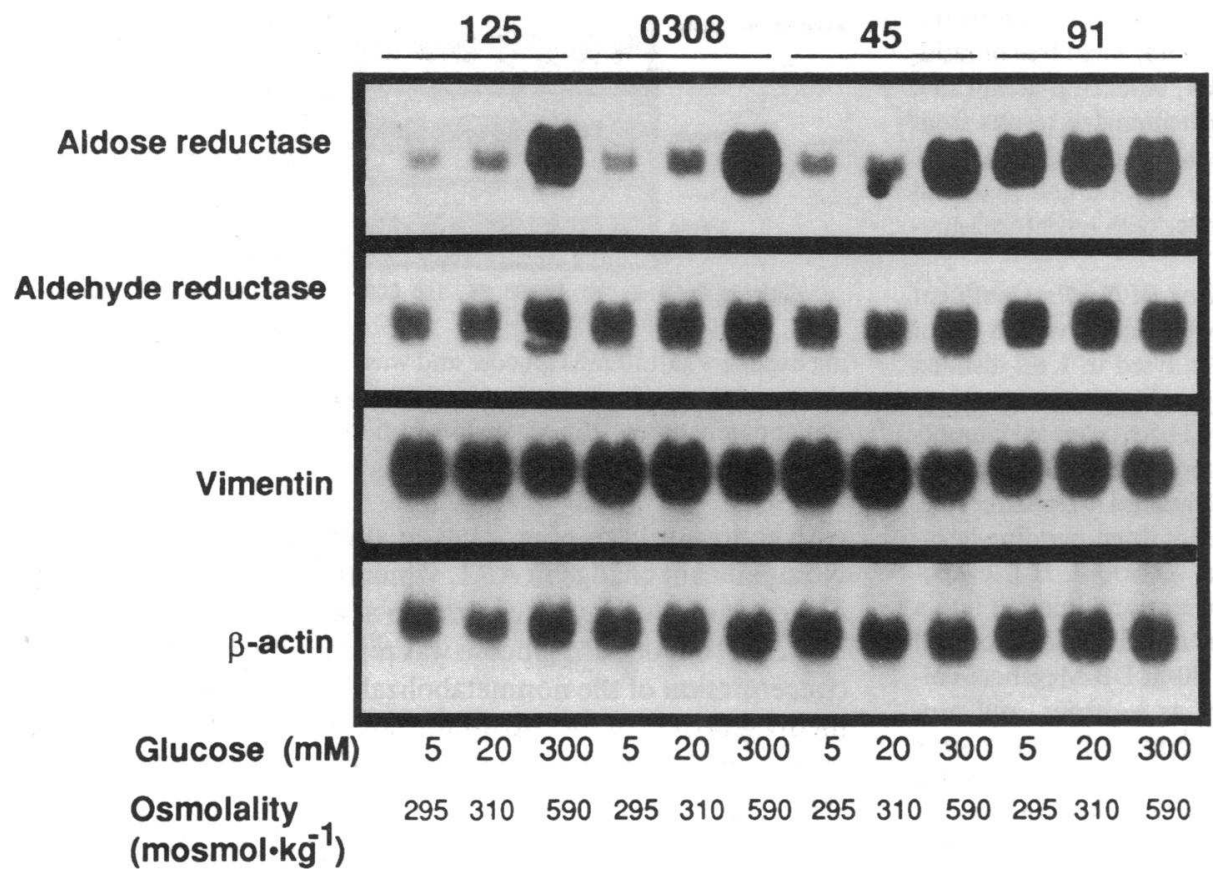

Figure 4. Osmotic induction of AR2 mRNA in different human RPE cell lines. RNA was isolated from four different RPE cell lines after $24 \mathrm{~h}$ exposure to 5,20 , or $300 \mathrm{mM}$ glucose. A Northern blot was sequentially hybridized with AR1, AR2, $\beta$-actin, and vimentin cDNA probes and autoradiograms were prepared. AR 1 and AR2 mRNA were normalized to $\beta$-actin as described in Methods. RPE cell lines 125, 0308, and 45 had marked increases in AR2 mRNA in response to $300 \mathrm{mM}$ glucose, but not to pathophysiologic hyperglycemia ( $20 \mathrm{mM}$ glucose). In contrast, RPE cell line 91 had a high basal level of AR2 mRNA and demonstrated little increase in AR2 mRNA in response to $300 \mathrm{mM}$ glucose. No significant change in ARI was detected in any of these conditions when normalized to $\beta$-actin mRNA. No change in vimentin or $\beta$ actin mRNA was evident in any cell line under any condition.
Metabolic correlates of constitutive vs. regulated $A R 2$ gene expression. The metabolic correlates of regulated or constitutive high level AR2 gene expression were assessed by comparing time-dependent changes in sorbitol and MI content in RPE 45 and 91 cells upon exposure to hyperglycemic ( $20 \mathrm{mM}$ glucose, $310 \mathrm{mosmol} / \mathrm{kg})(20)$ and hyperosmolar concentrations of glucose ( $300 \mathrm{mM}$ glucose, $590 \mathrm{mosmol} / \mathrm{kg}$ ) (Fig. 7). RPE 45 cells, with regulated AR2 gene expression, demonstrated little or no sorbitol accumulation and inconsistent MI depletion $24 \mathrm{~h}$ after exposure to either 20 or $300 \mathrm{mM}$ glucose, and significant sorbitol accumulation ( $164.6 \mathrm{~nm} / \mathrm{mg}$ protein $)$ and consistent MI depletion ( $32.4 \mathrm{~nm} / \mathrm{mg}$ protein to $8.3 \mathrm{~nm} / \mathrm{mg}$ protein, $P<0.001$ ) only after $7 \mathrm{~d}$ in $300 \mathrm{mM}$ glucose. In con-

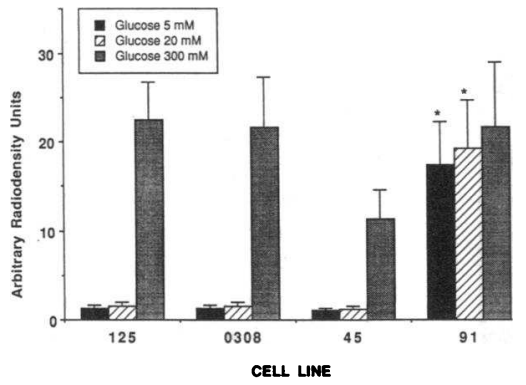

Figure 5. Quantitation of AR2 mRNA in RPE cells. AR2 mRNA was quantitated in total cellular RNA by dot blot hybridization of total RNA isolated $24 \mathrm{~h}$ after exposure of RPE cells to 5,20 , and $300 \mathrm{mM}$ glucose. The results from three independent experiments were quantitated using a laser densitometer. The radiodensity obtained was corrected for differences in $\beta$-actin abundance before statistical analysis. There was no difference in AR2 mRNA abundance between 5 and $20 \mathrm{mM}$ glucose in any cell.type. An effect of glucose on AR2 mRNA was evident only in RPE cell lines 125, 0308 , and $45(P<0.02)$. The level of AR2 mRNA in RPE 91 cells exposed to 5 or $20 \mathrm{mM}$ glucose was significantly higher than any. other cell line $\left({ }^{*} P<0.001\right)$. The basal level of AR2 mRNA in RPE 91 cells was $14-$ to 17 -fold higher than that in any other cell type. trast, modest sorbitol accumulation $(42.8 \mathrm{~nm} / \mathrm{mg}$ protein ) was detectable in RPE 91 cells within $24 \mathrm{~h}$ of exposure to $20 \mathrm{mM}$ glucose, and marked sorbitol accumulation and $\mathrm{MI}$ depletion were evident (sorbitol, $428.7 \mathrm{~nm} / \mathrm{mg}$ protein, $P<0.001$; MI, $29.6 \mathrm{~nm} / \mathrm{mg}$ protein to $11.4 \mathrm{~nm} / \mathrm{mg}$ protein, $P<0.001$ ) in 300 $\mathrm{mM}$ glucose. After $7 \mathrm{~d}$, sorbitol accumulation $(468.6 \mathrm{~nm} / \mathrm{mg}$ protein, $P<0.001)$ and MI depletion $(44.0 \mathrm{~nm} / \mathrm{mg}$ protein to $1.7 \mathrm{~nm} / \mathrm{mg}$ protein, $P<0.001$ ) was clearly exaggerated in RPE 91 cells compared with RPE 45 cells at $20 \mathrm{mM}$ and $300 \mathrm{mM}$ glucose.

\section{Discussion}

RPE cell lines from three human donors (RPE cell lines 125, 0308, and 45) exhibited low basal levels of AR2 mRNA when cultured in isotonic medium and an 11- to 18-fold increase in AR2 mRNA in response to $300 \mathrm{mM}$ glucose. These results are similar to those reported in a variety of renal and nonrenal cells, including rat glomerular mesangial cells, dog kidney endothelial cells, dog and rat lens epithelial cells, and Chinese hamster ovary cells, $(7,12,29-35)$. The response required $8 \mathrm{~h}$, was maximal at $16 \mathrm{~h}$, and required at least $150 \mathrm{mM}$ glucose $(445$ mosmol $/ \mathrm{kg}$ ). Lesser glucose concentrations did not increase AR2 mRNA in any RPE cell line. AR1 mRNA was not significantly altered by hyperosmolar conditions up to $590 \mathrm{mosmol} /$ $\mathrm{kg}$, suggesting that AR 1, an oxido-reductase capable of metabolizing glucose to sorbitol is unlikely to play a significant role in the cellular adaptation to a hyperosmolar stress. However, a fourth cell line (RPE 91), isolated and cultured under conditions identical to the other RPE cells, exhibited high basal AR2 gene expression and little increase of AR2 mRNA in response to hyperosmolarity produced by glucose, 3-O-methylglucose, or mannitol. This observation suggests that the expression of AR2 gene in RPE 91 cells is unregulated. Further support for 


\section{RPE CELL LINE}

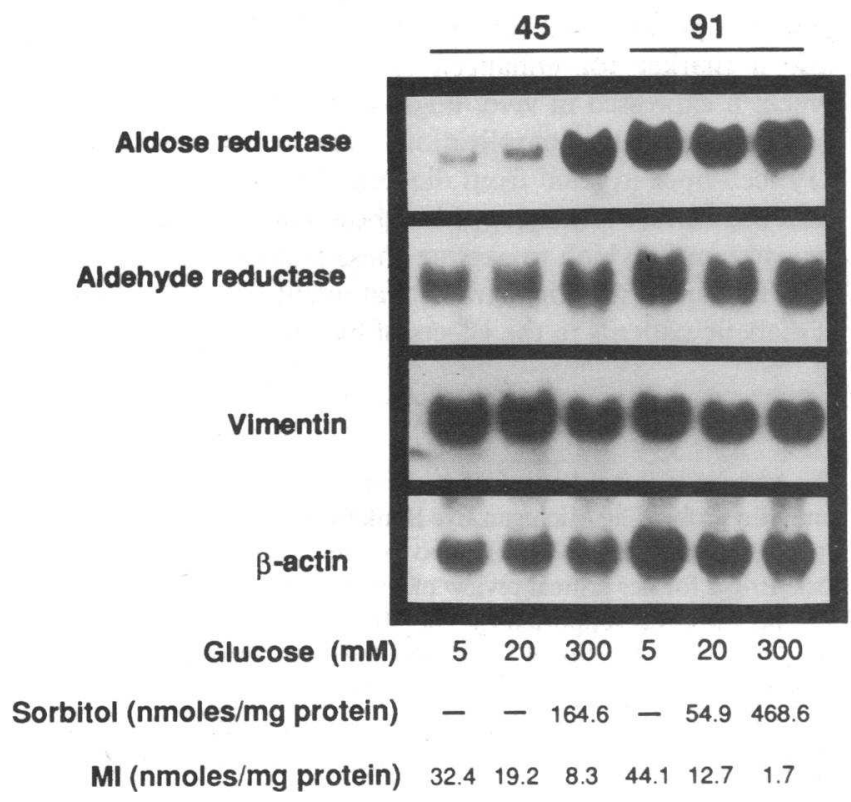

7 day exposure

Figure 6. Effect of chronic exposure to glucose. RPE cell lines 45 and 91 were exposed to $20 \mathrm{mM}$ or $300 \mathrm{mM}$ glucose for $7 \mathrm{~d}$ before RNA isolation. A Northern blot was sequentially hybridized with AR 1 , AR2, $\beta$-actin, and vimentin cDNA probes. Twenty $\mathrm{mM}$ glucose did not increase AR2 mRNA in RPE 45 even after $7 \mathrm{~d}$ exposure. 300 mM glucose increased AR2 mRNA in RPE 45 cells but the steadystate level after $7 \mathrm{~d}$ was $30 \%$ of that noted at $24 \mathrm{~h}$. RPE 91 had a 17-fold higher basal level of AR2 mRNA than the basal level of RPE 45 cells. No significant change in AR1, vimentin, or $\beta$-actin was evident. this hypothesis derives from studies of the dynamic effects of 7-d exposure to $300 \mathrm{mM}$ glucose. After an acute increase in AR2 mRNA, RPE 45 cells subsequently demonstrated a $30 \%$ decrease in AR2 mRNA levels between 1 and $7 \mathrm{~d}$, which was prevented by treatment with the aldose reductase inhibitor, sorbinil (36). The decline in AR2 mRNA in RPE 45 cells may be due to the "feedback" effect of metabolites of the enzymatic reaction catalyzed by $A R 2$ (e.g., sorbitol accumulation), as has been proposed for renal medulla (37). Despite the presence of markedly elevated sorbitol levels in RPE 91 cells (nearly threefold greater than RPE 45), AR2 mRNA levels were unchanged after $7 \mathrm{~d}$ exposure to $300 \mathrm{mM}$ glucose. These data would suggest that AR2 gene expression in RPE 91 cells is unresponsive to both hyperosmotic stimuli and to putative feedback inhibition by polyol pathway intermediates, consistent with the hypothesis that the AR2 gene is essentially unregulated in RPE 91 cells.

The regulation of the AR2 gene expression has been studied best in the renal medulla, where sorbitol is one of several alternative non-ionic organic intracellular osmolytes produced in response to the physiological extracellular hyperosmolarity associated with antidiuresis (7). This "nonperturbing" class of intracellular organic osmolytes, which includes sorbitol, MI, betaine, and glycerophosphorylcholine $(7,11,32,33)$, maintains intracellular osmolarity without disrupting the intracellular ionic environment (7). Extracellular hyperosmolarity has been shown to increase AR2 gene transcription and AR2 mRNA stability, leading to an increased steady-state level of AR2 mRNA (38) and subsequently AR2 protein (34). Similar mechanisms likely underlie the expression of relevant transporters and/or enzymes for the alternative nonperturbing osmolytes $(11,12,35)$ in renal medullary tubular cells. Osmotic induction of AR2 and MI transport has also been described in
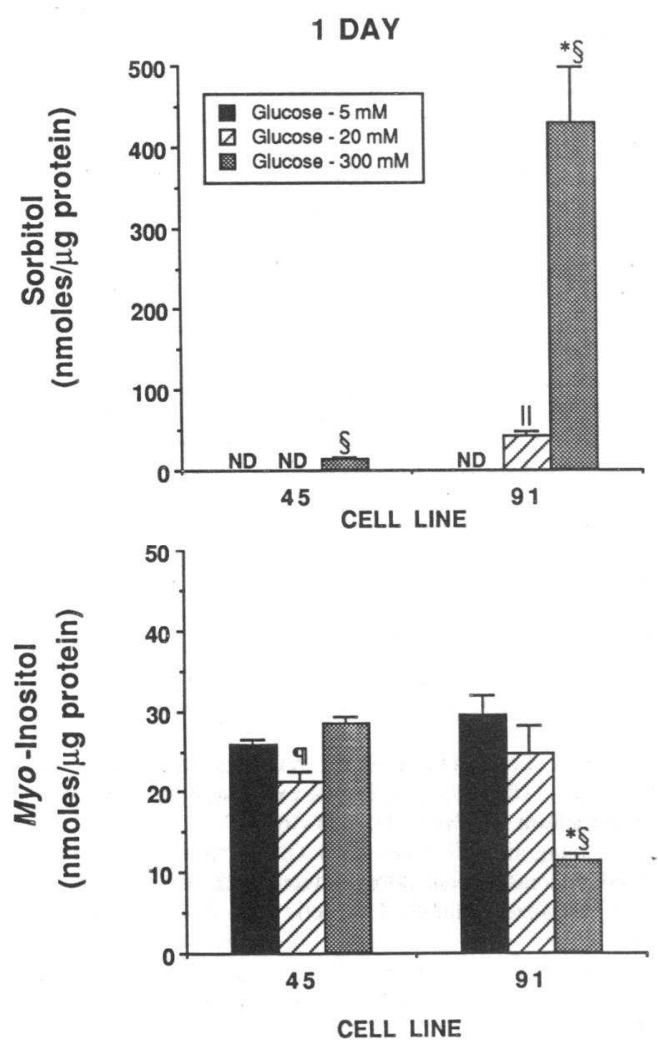
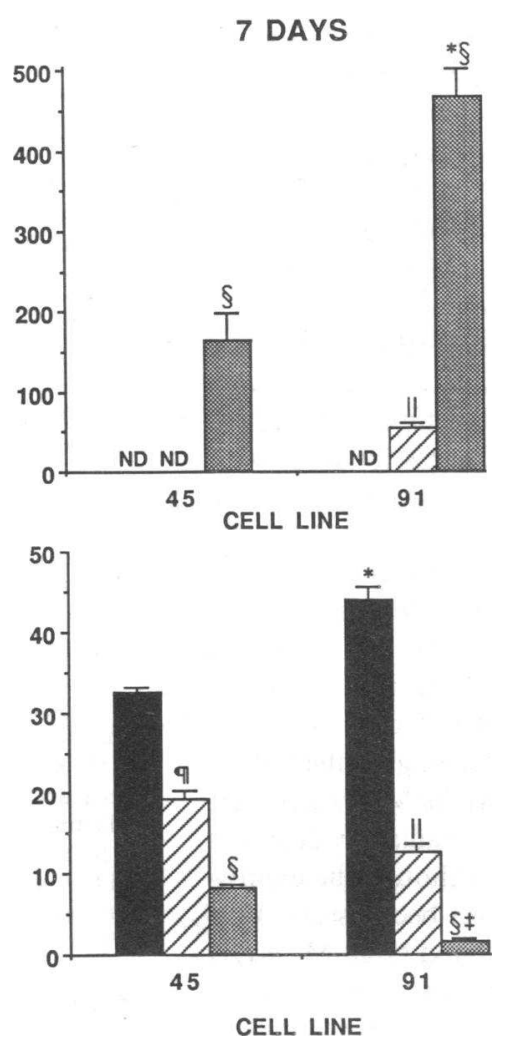

Figure 7. Metabolic consequences of high constitutive AR2 expression. Levels of sorbitol and $m y o$-inositol ( $\mathrm{nmol} / \mathrm{mg}$ protein) were determined in RPE cell lines 45 (regulated AR2 expression) and 91 (constitutive high level AR2 expression) after 1 and $7 \mathrm{~d}$ exposure to 5,20 , or $300 \mathrm{mM}$ glucose. RPE 91 demonstrated accelerated sorbitol accumulation and a profound depletion of $\mathrm{MI}$ at both hyperglycemic ( $20 \mathrm{mM}$ glucose) and hyperosmolar ( $300 \mathrm{mM})$ glucose conditions. RPE 45 had sorbitol detected only in $300 \mathrm{mM}$ glucose and MI depletion only after $7 \mathrm{~d}$ exposure to hyperglycemic or hyperosmolar conditions. *Significantly different from respective condition in RPE 45 $(P<0.001)$. 'Significantly different from respective condition in RPE $45(P<0.02)$. Significantly different from 5 and $20 \mathrm{mM}$ glucose $(P<0.001)$. "Significantly different from 5 and $300 \mathrm{mM}$ glucose $(P<0.001)$. 'Significantly different from 5 and $300 \mathrm{mM}$ glucose $(P<0.05)$. 
extramedullary renal cells and in nonrenal cells rarely or never exposed to significant physiologic hyperosmolarity in vivo ( 31 , 39). Thus, the AR2 gene is likely expressed at basal levels in most mammalian cells unless induced by degrees of hyperosmolarity only rarely encountered outside the renal medulla. It would follow that physiologically significant polyol pathway activity in nonrenal tissues is for practical purposes restricted to pathologically elevated glucose concentrations of diabetes that stimulate AR2 activity through mass action rather than gene induction.

Constitutive high AR2 gene expression in RPE 91 cells in $20 \mathrm{mM}$ glucose (20), was associated with exaggerated sorbitol accumulation and MI depletion. Indeed, RPE 91 cells exhibit greater sorbitol accumulation and MI depletion than RPE 45 cells even after $7 \mathrm{~d}$ in $300 \mathrm{mM}$ glucose despite comparable AR2 mRNA levels. This presumably reflects the delayed accumulation of the AR2 protein in the RPE 45 cells, which may have not yet reached steady-state levels even after $7 \mathrm{~d}$ due to the prolonged metabolic half-life of the AR2 protein (40). If constitutive overexpression of the AR2 gene occurs in vivo, it would probably exaggerate those metabolic consequences of hyperglyemia mediated by the sorbitol pathway, such as MI depletion. MI depletion by substrate-induced (rather than osmotically induced) activation of the polyol pathway in diabetes may itself represent a compensatory shift of alternative intracellular organic osmolytes in an isoosmotic environment (32). Since substrate-induced, iso-osmotic sorbitol accumulation would be unaccompanied by osmotic induction of MI accumulation, MI levels could reach levels sufficiently low as to limit phosphatidylinositol synthesis (20). This degree of MI depletion has been produced in RPE 91 cells with high constitutive AR2 gene expression by brief exposure to $20 \mathrm{mM}$ glucose, and such alterations in phosphoinositide metabolism have been invoked in the pathogenesis of some diabetic complications (41).

Pathways of glucose metabolism whose flux varies with prevailing hyperglycemia are often invoked as potential mediators of the chronic diabetic complications whose cumulative duration and severity parallel that of hyperglycemia $(2,42)$. Yet these metabolic pathways, such as nonenzymatic glycation and the polyol pathway, are rarely invoked to explain the wide variation of diabetic complications among patients with hyperglycemia of similar degree and duration (1 ). Fragmentary but nevertheless provocative data now link the tissue-specific catalytic capacity or protein content of aldose reductase-like enzymes with the prevalence and/or severity of diabetic complications $(13,15)$. The availability of cDNA sequences for RPE AR1 and AR2, and the delineation of the structure of the human AR2 gene (43) provide highly specific tools to independently study normal and abnormal regulation of these genes.

The mechanism underlying constitutive high level AR2 gene expression in RPE 91 cells is unknown, but defects in transcriptional regulation and/or mRNA stability represent likely candidates. This defect may represent only one of a broad range of osmoregulatory defects that might affect other "hypertonicity stress proteins" (11) such as the MI transporter. The possibility of a more generalized osmoregulatory defect in RPE 91 cells has not yet been excluded. Although the expression of the MI transporter gene has not yet been assessed directly in RPE 91 cells, the absence of elevated basal MI levels (20) and the rapid fall in MI induced by exposure to hyperglycemic or hyperosmolar concentrations of glucose certainly would argue against its constitutive overexpression, and would suggest a more limited defect, perhaps confined to the AR2 gene. It is possible that elucidation of this defect $(s)$ might provide a marker for enhanced sensitivity to hyperglycemia, which, if expressed in vivo, might constitute a significant risk factor for diabetic complications. The ready availability of RPE cell lines isolated from diabetic donors by new and efficient cell culture technology (44) should provide an important new system in which to explore these possibilities and potentially to identify genetic markers that might sensitize subgroups of diabetic patients to the effects of hyperglycemia.

\section{Acknowledgments}

The authors wish to thank Vishva Dixit for the generous gift of the vimentin probe; The Michigan Eye Bank for human donor eyes; Mary Brennan, Lisa Beyer, and Joe Chapo for their technical assistance; and Josie Briggs for her critical review of this manuscript.

This work was supported by The Michigan Diabetes Research and Training Center (National Institutes of Health 5P60-DK20572) and National Institutes of Health RO1-DK38304 (D. A. Greene). D. N. Henry was supported by Juvenile Diabetes Foundation Postdoctoral Fellowship 390046 and National Institute of Child Health and Human Development-National Institutes of Health Center Grant 1-P30-HD28820. P. D. Killen was supported by National Institutes of Health 2PO1-HL31963, 1P50-DK39255, and 1RO1-DK44848.

\section{References}

1. Rosenstock, J., and P. Raskin. 1988. Diabetes and its complications: blood glucose controls genetic susceptibility. Diabetes Metab. Rev. 4:417-435.

2. Beyer, T. A., and N. J. Hutson. 1986. Evidence for the role of polyol pathway in the pathophysiology of diabetic complications. Metab. Clin. Exp. 35:1-4.

3. Srivastava, S. K., N. H. Ansari, G. A. Hair, S. Awasthi, and B. Das. 1986 Activation of human erythrocyte, brain, aorta, muscle, and ocular tissue aldose reductase. Metab. Clin. Exp. 35:114-118.

4. Greene, D. A., S. A. Lattimer, and A. F. Sima. 1987. Sorbitol, phosphoinositides, and sodium-potassium-ATPase in the pathogenesis of diabetic complications. N. Engl. J. Med. 316:599-606.

5. Greene, D. A., P. V. DeJesus, and A. I. Winegrad. 1975. Effect of insulin and dietary myoinositol on impaired peripheral motor nerve conduction velocity in acute streptozotocin diabetes. J. Clin. Invest. 55:1326-1336.

6. Nakamura, J., M. A. DelMonte, D. Shewach, S. A. Lattimer, and D. A. Greene. 1992. Inhibition of phosphatidylinositol synthase by glucose in human retinal pigment epithelial cells. Am. J. Physiol. 262:E417.

7. Garcia-Perez, A., and M. B. Burg. 1991. Role of organic osmolytes in adaptation of renal cells to high osmolality. J. Membr. Biol. 119:1-13.

8. Morrison, A. D., R. S. Clements, S. B. Travis, F. Oski, and A. I. Winegrad. 1970. Glucose utilization by the polyol pathway in human erythrocytes. Biochem. Biophys. Res. Commun. 40:199-205.

9. Williamson, J. R., E. Ostrow, D. Eades, K. Chang, C. Kilo, and W. R. Sherman. 1990. Glucose induced mirovascular functional changes in non-diabetic rats are steriospecific and are prevented by an aldose reductase inhibitor. $J$. Clin. Invest. 85:1167-1172.

10. Kinoshita, J. H. 1974. Mechanism initiating cataract formation. Invest. Ophthalmol. 13:713-724.

11. Kwon, H. M., A. Yamauchi, S. Uchida, A. S. Preston, A. Garcia-Perez M. B. Burg, and J. S. Handler. 1992. Cloning of the cDNA for a Na+/myo-Inositol cotransporter, a hypertonicity stress protein. J. Biol. Chem. 267:6297-6301.

12. Cowley, B. D., J. D. Ferraris, D. Carper, and M. B. Burg. 1990. In vivo osmoregulation of aldose reductase mRNA, protein, and sorbitol in renal medulla. Am. J. Physiol. 258:F154-161.

13. Vinores, S. A., P. A. Campochiaro, E. H. Williams, E. E. May, W. R. Green, and R. L. Sorenson. 1988. Aldose reductase expression in human retina and retinal pigment epithelium. Diabetes. 37:1658-1664.

14. Ghahary, A., L. Jiangming, G. Yuewen, S. Chakrabarti, A. A. F. Sima and L. J. Murphy. 1989. Increased renal aldose reductase activity, immunoreactivity, and mRNA in streptozocin-induced diabetic rats. Diabetes. 38:10671071 .

15. Hamada, Y., R. Kitoh, and P. Raskin. 1991. Crucial role of aldose reductase activity and plasma glucose level in sorbitol accumulation in erythrocytes from diabetic patients. Diabetes. 40:1233-1240. 
16. MacGregor, L. C., and F. M. Matschinsky. 1986. Altered retinal metabolism in diabetes. II. Measurement of sodium-potassium ATPase and total sodium and potassium in individual retinal layers. J. Biol. Chem. 261:4052-4058.

17. MacGregor, L. C., L. R. Rosecan, A. M. Laties, and F. M. Matschinsky. 1986. Altered retinal metabolism in Diabetes. I. Microanalysis of lipid, glucose sorbitol, and myo-inositol in the choroid and in the individual layers of the rabbit retina. J. Biol. Chem. 261:4046-4051.

18. MacGregor, L. C., and F. M. Matschinsky. 1985. Treatment with aldose reductase inhibitor or with myo-inositol arrests deterioration of the electroretinogram of diabetic rats. J. Clin. Invest. 76:887-889.

19. Khatami, M. 1990. Kinetics of myo-inositol transport in corneal endothelial cells: diverse effects of sugars and implications in corneal deutergence. Membr. Biochem. 9:91-106.

20. Del Monte, M. A., R. Rabbani, T. C. Diaz, S. A. Lattimer, J. Nakamura, M. C. Brennan, and D. A. Greene. 1991. Sorbitol, myo-inositol and rod outer segment phagocytosis in glucose-exposed cultured human retinal pigment epithelial cells: in vitro modeling of the myo-inositol depletion hypothesis of diabetic complications. Diabetes. 40:1335-1345.

21. Del Monte, M. A., and I. H. Maumenee. 1980. New techniques for in vitro culture of human retinal pigment epithelium. Birth Defects Orig. Artic. Ser. 16:327-338.

22. Stallcup, M. R., and L. D. Washington. 1983. Region-specific initiation of mouse mammary tumor virus RNA synthesis by endogenous RNA polymerase II in preparations of cell nuclei. J. Biol. Chem. 258:2802-2807.

23. Bohren, K. M., B. Bullock, B. Wermuth, and K. H. Gabbay. 1989. The aldo-keto reductase superfamily. J. Biol. Chem. 264:9547-9551.

24. Feinberg, A. P., and B. Vogelstein. 1983. A technique for radiolabeling DNA restriction endonuclease fragments to high specific activity. Anal. Biochem. 132:6-13.

25. Church, G. M., and W. Gilbert. 1984. Genomic sequencing. Proc. Natl. Acad. Sci. USA. 81:1991-1995.

26. Cleveland, D. W., M. A. Lopata, R. I. McDonald, N. J. Cowan, W. J. Rutter, and M. W. Kirschner. 1980. Number and evolutionary conservation of alpha- and beta-tubulin and cytoplasmic beta- and gamma-actin genes using specific cloned cDNA probes. Cell. 20:95-105.

27. Dixit, V. M., R. Marks, V. Sarma, and E. V. Prochownik. 1989. The animitogenic action of tumor necrosis factor is associated with AP-1/c-jun protooncogene transcription. J. Biol. Chem. 264:16905-16909.

28. SYSTAT. 1992. Statistics, Version 5.2 Edition. SYSTAT, Inc., Evanston, IL. 724 pp.

29. Hohman, T. C., and D. Carper. 1990. Hypertonic stress induces aldose reductase and myoinositol accumulation in lens epithelial, kidney endothelial, and Chinese hamster ovary cells. Current Concepts of Aldose Reductase and Its Inhibitions. N. Sakamoto, editor. Excerpta Medica, New York. 31-41.

30. Beckhor, I., S. Shi, D. Carper, C. Nishimura, and N. J. Unakar. 1989.
Relative abundance of aldose reductase mRNA in rat lens undergoing development of osmotic cataracts. C. Eye Res. 8:1299-1308.

31. Carper, D., M. Kaneko, H. Stark, and T. Hohman. 1990. Increase in aldose reductase mRNA in dog lens epithelial cells under hypertonic conditions. Exp. Eye Res. 50:743-749.

32. Moriyama, T., A. Garcia-Perez, and M. B. Burg. 1990. Factors affecting the ratio of different organic osmolytes in renal medullary cells. Am. J. Physiol. 259:F847-F858

33. Nakanishi, T., and M. B. Burg. 1989. Osmoregulation of glycerophosphorylcholine content in mammalian renal cells. Am. J. Physiol. 257:C795C780.

34. Uchida, S., A. Garcia-Perez, H. Murphy, and M. Burg. 1989. Signal for induction of aldose reductase in renal medullary cells by high expernal $\mathrm{NaCl}$. $\mathrm{Am}$. J. Physiol. 256:C614-C620.

35. Kaneko, M., D. Carper, C. Nishmua, J. Millen, M. Bock, and T. C. Hohman. 1990. Induction of aldose reductase expression in rat kidney mesangial cells and Chinese hamster ovary cells under hypertonic conditions. Exp. Cell Res. 188:135-140.

36. Stevens, M., D. Henry, and P. Killen. 1992. Bi-directional exertion of intracellular myo-inositol content in response to glucose and hyperosmolality in cultured human retinal pigment epithelial cells. Diabetes. 42(Suppl.):81A.

37. Bondy, C., D. B. Cowley, S. L. Lightman, and P. F. Kador. 1990. Feedback inhibition of aldose reductase gene expression in rat renal medulla. J. Clin. Invest. 86:1103-1108.

38. Smardo, F. L., M. B. Burg, and A. Garcia-Perez. 1992. Kidney aldose reductase gene transcription is osmotically regulated. Am. J. Physiol. 262:C776782.

39. Strange, K., R. Morrison, C. W. Heilig, S. DiPietro, and S. R. Gullans. 1991. Upregulation of inositol transport mediates inositol accumulation in hyperosmolar brain cells. Am. J. Physiol. 260:C784-790.

40. Serena, M. B., H. R. Murphy, J. J. Bedford, and M. A. Burg. 1988. Osmoregulation by slow changes in aldose reductase and rapid changes in sorbitol flux. Am. J. Physiol. 254:C788-C792.

41. Greene, D. A., S. A. Lattimer, and A. A. Sima. 1988. Are disturbances of sorbitol, phophoinositol, and the $\mathrm{Na} / \mathrm{K}$ ATPase regulation involved in the pathogenesis of diabetic neuropathy. Diabetes. 37:688-693.

42. Brownlee, M., A. Cerami, and H. Vlassara. 1988. Advanced glycosylation end products in tissue and the biochemical basis of diabetic complications. $N$. Engl. J. Med. 318:1315-1321.

43. Graham, A., L. Brown, P. J. Hedge, A. J. Gammack, and A. F. Markham 1991. Structure of the human aldose reductase gene. J. Biol. Chem. 266:68726877.

44. Miceli, M. V., and D. A. Newsome. 1991. Cultured retinal pigment epithelium cells from donors with type I diabetes show an altered insulin response. Invest. Ophthalmol. \& Vis. Sci. 32:2847-2859. 